\title{
Karlovy Vary 99
}

\author{
By Ron Holloway \\ Spring 2000 Issue of KINEMA
}

\section{THE 34th KARLOVY VARY INTERNATIONAL FILM FESTIVAL}

One film can make a festival unforgettable. That film at the 34th Karlovy Vary International Film Festival (2-11 July 1999) was G.W. Pabst's Der Schatz (The Treasure, Germany, 1923), a restored print of a previously declared lost classic presented in the restored Divadlo (Czech for "theatre") opera house - a splendid decorative edifice dating from 1886, when it opened with Mozart's "Marriage of Figaro" and now reopened after a 10-year reconstruction effort. Not only was Pabst's first feature film pieced together by the Prague Film Archive in collaboration with the Stiftung Deutsche Kinemathek in Berlin and the Cinematheque Royale in Brussels, but Max Deutsch's original score for the film's premiere in Dresden on 26 February 1923 was also found in the archive of the Frankfurt Film Museum. Another stroke of good fortune, for Deutsch's score is historically recognized as the first complete film symphony and was obtained from the composer himself before the student of Arnold Schoenberg and professor at the Paris Conservatory died in 1982.

Put all these finds together, win the support of the Kirch Group to sponsor the Karlovy Vary event, and you have the reenactment of the original film symphony in five movements performed by the Czech Symphony Orchestra under the baton Frank Strobel. Upon its completion, the applause thundered on and on, as though this moment too should be preserved in time. As for the film itself, the Froelich-Film production was inspired by Rudolf Hans Bartsch's fad-novella and molded in Pabst's hands into one of the last instances of pure film expressionism. Architects Walter Röhrig (Caligari) and Robert Herlth (Der müde Tod) collaborated on the sets, through which a cast of eminent stage-and-screen actors move like ghosts rather than humans. Albert Steinrück, heavy and demonic, plays the greedy Slovenian bell-founder, in whose house-workshop lies a legendary treasure from the days of the Turkish marauders. Lucie Mannheim plays his enchanting daughter, courted by the handsome Hans Brausewetter, both representative of a modern generation of progressive idealists. These figures in turn contrast with the persona of Werner Krauss, who plays the superstitious, berserk, altdeutsch treasure-seeker, who wanders nightly through the winding corridors of the cavernous house with a wishing-wand in his hands.

The International Jury awarded the Crystal Globe to Arik Kaplun's Yana's Friends (Israel), a socio-critical tragicomedy with a fairy-tale ending. The entry might just as well pass for a Russian film, for nearly all of Yana's "friends" are Russian emigrants - fools and adventurers, dreamers and conmen, good and bad people, who have arrived in the "promised land" with converging hopes and half-baked schemes. Yana, herself a naive newly-wed with a baby on the way, no sooner arrives in Tel Aviv than her husband hi-tails it back to Moscow "for business reasons" with a bank loan obtained under her signature. Other emigrants don't fare much better: neighbors are on each other's backs, some seek a place in the sun without the burden of work, others search for work without much success, a few dream of moving on to America at the first opportunity. An honest and open-ended film that augurs well for Israeli cinema today. Evlyn Kaplun, charming and vulnerable as Yana, was awarded Best Actress.

A trio of films on teenage hysteria and the quandary of youth in provincial towns were audience favourites. Lukas Moodysson's Fucking Amål (Show Me Love, Sweden-Denmark), a winsome comedy set in a backwater town where nothing ever happens, received the Grand Prize of the Jury. Michael Patrick Jann's Drop Dead Gorgeous (USA), a satire on teenage beauty contests set in Mount Rose, Minnesota, hits all the harder because this nutty local event, the most important social event of the year, is viewed through the camera of a hyped documentary film team. And Janez Burger's V leru (Idle Running, Slovenia), a black-and-white low-budget entry, deals with university students in Ljubljana who waste their time in dormitories playing cards, drinking beer, and watching television. When Dizzi, a hangabout nihilist, is assigned a roommate from the sticks, whose girlfriend is pregnant and has to share the room with them, life suddenly takes an unexpected turn - for all concerned. Idle Running is a runaway hit in Slovenian cinemas.

Young recruits coming of age under questionable military circumstances in the Russian army is what makes 
Alexander Rogozhkin's Blockpost (Checkpoint, Russia) one of the best antiwar films to emerge from eastern Europe this decade. When a squad of young soldiers are blamed for a bloody incident in a Caucasus village, they are sent to an outpost on the front without the slightest idea of why they are there and who the enemy sniper is that constantly takes potshots at them. Meanwhile, the rest of the Islamic population tolerates the checkpoint, if only to facilitate passage to and fro over the border - and to obtain cartridges from a naive recruit in exchange for sex. Rogozhkin, who had previously received the Grand Prize for the Russian competition at the Sochi film festival, was awarded Best Director.

The first Philip Morris Freedom Prize for an entry in the "East of West" section - open to films from, or dealing with, what was formerly Eastern Europe - was awarded to Pyotr Lutsik's Okraina (Outskirts, Russia). Returning to a 1930s tradition of romantic realism in Soviet cinema, particularly with the reference to Boris Barnet's Okraina (USSR, 1933) in the title, Lutsik narrates in powerful images a modern-day uprising in the provinces against corruption and bureaucracy in the distant capital of Moscow.

For his convincing portrayal of a former GDR factory manager in Andreas Kleinert's Wege in die Nacht (Paths in the Night, Germany) Hilmar Thate was awarded Best Actor. The 55-year-old Walter, at heart an idealist and formerly a man of position and power, can barely stomach being unemployed and living off his wife's earnings as a waitress. Spurred on by an undying belief in a better world, he recruits a pair of simple-minded youngsters to ride Berlin's underground and city trains - his "paths in the night" - in search of vigilante actions to do good and fight evil, with fatal consequences.

HTML clipboardLastly, New Czech Cinema continues to amaze with its diversity of directorial talent. Jan Hřebejk's Pelíšky (Cozy Dens), a competition entry awarded the FIPRESCI Prize, leans effectively on a rich tradition of Czech humour to depict the lives of neighboring families in the months just prior to the Soviet invasion of Prague in August of 1968. Ivo Traijkov's Minulost (The Past), the second feature by a filmmaker of Czech and Macedonian descent, deftly combines sound and images to relate the story of a deaf-and dumb man who has to piece together his past upon being released from prison for killing a man in the act of humiliating the girl whom the mute man had loved. Roman Vávra's Co chytneš v žitě (In the Rye), a trilogy of short features penned by different scriptwriters and photographed by different cameramen, is set in a magical field of rye during different seasons of the year, each story offering the director the opportunity to experience with another genre and age generation. Mira Erdevicki-Charap's Black-and-White in Color, a documentary about gypsy singer Věra Bílá and her KALE group, not only impresses as a sensitive portrait of a gifted singer, but it also throws on the plight of her people in a changing Czech society that is becoming in some areas of the country ethnically intolerant. And Radim Špaček's Rychlé pohyby oči (Rapid Eye Movements), a graduation feature made at the Czech Film School (FAMU), takes the pulse of a young man living on the edge of society whose existentialist feelings (love, madness, death, suicide) are detailed in this fascinating self-styled "psychofilm."

\section{References}

\section{AWARDS}

International Competition

Karlovy Vary Crystal Globe (Grand Prix): Arik Kaplun's Hachaverim shel Yana (Yana's Friends, Israel)

Special Prize of the Jury: Lukas Moodysson's Fucking Amål (Show Me Love, Sweden-Denmark)

Best Director: Alexander Rogozhkin, Blockpost (Checkpoint, Russia)

Best Actress: Evlyn Kaplun, Hachaverim shel Yana (Yana's Friends, Israel)

Best Actor: Hilmar Thate, Wege in die Nacht (Paths in the Night, Germany)

Philip Morris Freedom Prize

Pyotr Lutsik's Okraina (Outskirts, Russia)

International Critics (FIPRESCI) Prize

Jan Hřebejk's Pelísky (Cozy Dens, Czech Republic) 


\section{Ecumenical Prize}

Gavin Hood's A Reasonable Man (South Africa)

\section{Author Information}

Ron HOLLOWAY (1933-2009) was an American critic, film historian, filmmaker and correspondent who adopted Europe as his home in the early fifties and spent much of his life in Berlin. He was an expert on the study of German cinema and against all odds produced, with his wife Dorothea, the journal German Film, keeping us up-to-date with the work of directors, producers and writers and the showing of German films around the world.

In 2007, Ron Holloway and his wife were awarded the Berlinale Camera Award. Ron also received the Bundesverdienstkreuz (German Cross of Merit), Polish Rings, Cannes Gold Medaille, the American Cinema Foundation Award, the Diploma for Support of Russian Cinema and an honorary award from the German Film Critics' Association.

Ron was also a valued contributor to Kinema for the past fifteen years. 